\title{
A Study on Histopathological Pattern of Ovarian Tumours in Chittagong Medical College Hospital
}

\author{
Mahmuda Begum ${ }^{1 *}$ \\ Md Mukhlesur Rahman ${ }^{2}$ \\ Mahmuda Jahan ${ }^{3}$ \\ Zillur Rahman' \\ Shahanara Chowdhury ${ }^{4}$ \\ 'Department of Pathology \\ Chittagong Medical College \\ Chattogram, Bangladesh. \\ ${ }^{2}$ Department of Otolaryngology-Head \& Neck Surgery \\ Chittagong Medical College \\ Chattogram, Bangladesh. \\ ${ }^{3}$ Department of Pathology \\ Southern Medical College \\ Chattogram, Bangladesh. \\ ${ }^{4}$ Department of Obstetrics \& Gynaecology \\ Chittagong Medical College \\ Chattogram, Bangladesh.
}

\author{
*Correspondence to: \\ Dr. Mahmuda Begum \\ Assistant Professor \\ Department of Pathology \\ Chittagong Medical College \\ Chattogram, Bangladesh. \\ Mobile : 8801716118147 \\ Email :drmahmuda1998@gmail.com
}

Date of Submission : 28.04 .2020

Date of Acceptance : 15.06 .2020

www.banglajol.info/index.php/CMOSHMCJ

\begin{abstract}
Background: Ovarian tumours may either be asymptomatic, found on the routine ultrasound examination or symptoms may be vague till the patient has an acute emergency like torsion or rupture of a benign cyst. The worst is late presentation of malignant ovarian tumour. There is marked variation in the presentation of the tumour as well as in histological types. This study was under taken to analyse modes of presentation and various histopathological patterns of ovarian tumour.
\end{abstract}

Materials and Methods: A total of 69 cases were selected consecutively. The age range was 13-70 years. This study was carried out in the Department of Pathology, Chittagong Medical College and Department of Gynaecology and obstetrics, Chittagong Medical College Hospital during the period from July 2013 to June 2014. The specimens of ovarian tumours were subjected to histopathological examination in the histopathology section.

Results : Out of 69 cases, 54(78.3\%) were benign and 15(21.7\%) were malignant tumour. There was no borderline malignancy in our study. The commonest histological pattern in this study was surface epithelial tumour 49(70.6\%) including both benign and malignant tumour followed by germ cell tumour 6(8.7\%). The commonest benign tumour was serous cyst cyst adenoma 23(33.4) and malignant tumour was serous cyst adenocarcinoma 5(7.2\%).

Conclusion : Surface epithelial tumours are the commonest variety of ovarian tumour followed by germ cell tumour. The histological type of ovarian tumour correlates with the prognosis of the tumour.

Key words: Histopathology; Ovarian tumour; Malignant; Benign tumour.

\section{INTRODUCTION}

Diverse histopathologies are common in ovarian tumours reflecting the different cell origins of the tumours ${ }^{1}$. Ovarian cancer represents the sixth most commonly diagnosed cancer among women in the world ${ }^{2}$. Majority of the ovarian tumour are benign $(80 \%)$ with cystic, solid or mixed characteristics. The remaining $(20 \%)$ of these tumours are malignant in nature and run a fatal prognosis. Furthermore, the lifetime risk of development of ovarian cancer is $5-7 \%$ and due to the fatal outcome of this disease, early and accurate diagnosis of ovarian tumour is needed. The detection and assessment of ovarian lesions are an important part of gynaecological practice. Advance knowledge of whether an overt ovarian mass is malignant may be useful for improving the effectiveness of surgical treatment ${ }^{3}$.

Ovaries are paired, pelvic female reproductive organs. The diagnosis of ovarian neoplasm depends on histopathological examinations as they are inaccessible for cytological techniques except when they are approached through image guidance ${ }^{4}$. 
The ovarian tumours manifest with wide spectrum of clinical, morphological and histological features. Screening for ovarian tumours are improved by various diagnostic modalities, such as Doppler Color flow ultrasonography and transvaginal ultrasonography, measurement of tumour markers such as serum HCG, serum CA-125, Serum alpha-fetoprotein, placental alkaline phosphatase and lactate dehydrogenase, ovarian cancer antigen OVXI and CA $15-3^{5}$.

The objective of our study is to determine the nature of various ovarian tumours and to ascertain their frequency and distribution.

In this study we tried to find out the histopathological patterns which are more prevalent in our population.

\section{MATERIALS AND METHODS}

It was a cross-sectional descriptive study was carried out in the Department of Pathology, Chittagong Medical College (CMC) in collaboration with Department of Gynaecology and Obstetrics, Chittagong Medical College Hospital (CMCH) from July 2013 to June 2014. All female Patients, presenting with ovarian tumuor as detected on clinical \& radiological evaluation in the Department of Gynaecology and Obstetrics, Chittagong Medical College Hospital were the study population. In this study total 69 cases were taken. It was non probability convenience sampling.

\section{Inclusion criteria}

Patients with following characteristics was included in the study:-

- Female patients of any age with clinical \& radiological evidence of ovarian mass who gave written informed consent for the study

- Patients who underwent surgery.

\section{Exclusion criteria}

- Those patients, who did not give written informed consent for the study

- Previously diagnosed patients of ovarian tumour.

Clinical history, questionnaire, thorough physical examination, and relevant investigations like USG were recorded in details in all cases. Serum CA-125 level was found in 37 cases.

\section{Histopathological examination}

i) All the specimens were fixed in $10 \%$ formalin.

ii) Gross examination of specimen was done. During gross examination particular emphasis on content of cystic mass, loculated or not, any visible papillary growth, area of necrosis were noted. Blocks were taken from different sites.

iii) Tissue processing: Routine tissue processing with paraffin impregnating was done .

iv) Staining: section prepared from the biopsy specimen was stained by H\&E stain and were examined under light microscope to get a definitive diagnosis of the tumours and its type.
All the necessary and relevant data regarding patients were recorded methodically in a data sheet. Data was processed and analyzed by using the SPSS (Statistic Package for Social Science) version-18 software package for windows.

\section{RESULTS}

The age range of the 69 patients was 13-70 years (Mean age was 36.38 years, $\mathrm{SD} \pm 14.15)$. The cases were divided into Six age groups and it was seen that maximum number of benign tumours $17(24.6 \%)$ were in age groups $21-30$ years and 15 (21.7\%) were 31-40 years age group. Maximum number of malignant tumours were found $5(7 \%)$ in age group 41-50 years and $5(7 \%)$ in 51-60 years respectively which is shown in Table-I.

Table-I : Distribution of ovarian tumours according to age group $(\mathrm{n}=69)$.

\begin{tabular}{rrrcr} 
Age Range & $\begin{array}{c}\text { Histopathological } \\
\text { Benign } \\
\text { tumour }\end{array}$ & $\begin{array}{c}\text { Diagnosis } \\
\text { Malignant } \\
\text { tumour }\end{array}$ & Total \\
1. & $20 \quad$ Years & 09 & 00 & $09(13.0 \%)$ \\
2. & $21-30$ Years & 17 & 03 & $20(29.0 \%)$ \\
3. & $31-40$ Years & 15 & 01 & $16(23.3 \%)$ \\
4. & $41-50$ Years & 05 & 05 & $10(14.4 \%)$ \\
5. & $51-60$ Years & 07 & 05 & $12(17.4 \%)$ \\
6. & $61-70$ Years & 01 & 01 & $02(2.9 \%)$ \\
& Total & $54(78.3 \%)$ & $15(21.7 \%)$ & $69(100.0 \%)$ \\
\hline
\end{tabular}

Among 37 cases, benign tumour was 26 (70.3\%) and malignant tumour was $11(29.7 \%) .21(56.2 \%)$ benign tumour cases was found within normal level and $10(27 \%)$ malignant cases was found increase level which is shown in Table-II.

Table-II : Association between ovarian tumours and serum CA -125 level $(n=37)$.

\begin{tabular}{llll} 
Type of tumour & $\begin{array}{l}\text { Normal level } \\
(\mathbf{0}-\mathbf{3 5} \mathbf{U} / \mathrm{ml})\end{array}$ & $\begin{array}{l}\text { Increased level } \\
(>\mathbf{3 5} \mathbf{U} / \mathrm{ml})\end{array}$ & Total \\
\hline Benign tumour & $21(56.7 \%)$ & $05(13.5 \%)$ & $26(70.3 \%)$ \\
Malignant tumour & $01(2.7 \%)$ & $10(27 \%)$ & $11(29.7 \%)$ \\
Total & $22(59.5 \%)$ & $15(40.5 \%)$ & $37(100.0 \%)$ \\
\hline
\end{tabular}

Chi-square $\left(\chi^{2}\right)=13.636, p=0.000$ (Highly Significant)

In this study it was seen that, majority $48(69.6 \%)$ cases had history of lower abdominal pain, $45(65.2 \%)$ cases had lower abdominal swelling and $11(15.9 \%)$ cases had vaginal bleeding which is shown in Table-III.

Table-III : Distribution According to clinical features $(n=69)$.

\begin{tabular}{llcc} 
Clinical Features & & Frequency & Percentage (\%) \\
Lower & Present & 48 & 69.6 \\
Abdominal Pain & Absent & 21 & 30.4 \\
Lower & Present & 45 & 65.2 \\
Abdominal Swelling & Absent & 24 & 34.8 \\
Vaginal bleeding & Present & 11 & 15.9 \\
& Absent & 58 & 84.1 \\
& Total & 69 & 100.0 \\
\hline
\end{tabular}


Histopathological diagnosis showed 54 (78.3\%) were benign tumour and $15(21.7 \%)$ were malignant tumour. Among benign tumour 23 (33.4\%) were serous cyst adenoma, 15 (21.6\%) were mucinous cyst adenoma, 04 (5.8\%) mature teratoma, 02 (2.9\%) fibroma, $2(2.9 \%)$ inflammatory lesions and $8(11.6 \%)$ were haemorrhagic cyst. Among malignant tumour, 5 (7.2\%) serous cyst adenocarcinoma, 4 (5.8\%) mucinous cyst adenocarcinoma, 1(1.4\%) endometrioid carcinoma, 1 (1.4\%) fibrosarcoma, $1(1.4 \%)$ yolksac tumour, $1(1.4 \%)$ clear cell carcinoma, $1(1.4 \%)$ struma ovarii, 1(1.4\%) granulosa cell tumour. The distribution is shown in Table-IV.

Table IV : Distribution of histopathology diagnosis and interpretations among the study subjects $(n=69)$.

$\begin{array}{llll}\begin{array}{lll}\text { Histopathological } \\ \text { impression }\end{array} & \text { Histopathological } & \text { No\% } & \begin{array}{l}\text { Total } \\ \text { No (\%) }\end{array} \\ & \text { Diagnosis } & & \text { Serous cyst adenoma } \\ & \text { Mucinous cyst adenoma } & 23(33.4) & 54(78.3 \%) \\ & \text { Haemorrhagic cyst } & 8(11.6) & \\ \text { Benign tumour } & \text { Mature teratoma } & 4(5.8) & \\ & \text { Fibroma } & 2(2.9) & \\ & \text { Inflammatory lesions } & 2(2.9) & \\ & \text { Serous cyst adenocarcinoma } & 5(7.2) & 15(21.7) \\ & \text { Mucinous cyst adenocarcinoma } 4(5.8) & \\ \text { Malignant tumour } & \text { Elear cell carcinoma } & 1(1.4) & \\ & \text { Endometrioid carcinoma } & 1(1.4) & \\ & \text { Fibro-sarcoma } & 1(1.4) & \\ & \text { Follicular variant of Papillary } & & \\ & \text { carcinoma within struma ovarii } & 1(1.4) & \\ & \text { Granulosa cell tumour } & 1(1.4) & \\ & \text { Yolk sac tumour } & 1(1.4) & \\ & \text { Total } & 69(100) & 69(100)\end{array}$

Among 69 ovarian tumour, 49 (70.6\%) was surface epithelial tumour, $6(8.7 \%)$ was germ cell tumour, $4(5.8 \%)$ was sexcordstromal tumours and $10(14.5 \%)$ was non neoplastic lesions. The distribution is shown in Table-V.

Table V : Distribution according to histological groups- $(n=69)$.

\begin{tabular}{llrr} 
Histological Groups & Sub Types & Frequency & \multicolumn{1}{c}{$\%$} \\
Surface epithilial & Serous cyst adenoma & 23 & 33.4 \\
tumour & Mucinous cyst adenoma & 15 & 21.4 \\
& Serous cyst adenocarcinoma & 5 & 7.2 \\
& Mucinous cyst adenocarcinoma & 4 & 5.8 \\
& Endometrioid carcinoma & 1 & 1.4 \\
& Clear cell carcinoma & 1 & 1.4 \\
Germ cell tumour & Mature cystic teratoma & 4 & 5.8 \\
& Yolk sac tumour & 1 & 1.4 \\
\multirow{5}{*}{ Sexcord- Stromal tmour } & Struma Ovarii & 1 & 1.4 \\
& Fibroma & 2 & 2.9 \\
\multirow{4}{*}{ Non neoplastic lesions Sarcoma } & 1 & 1.4 \\
& Granulosa cell tumour & 1 & 1.4 \\
Total & Inflammatory lesiosn & 8 & 11.6 \\
\hline
\end{tabular}

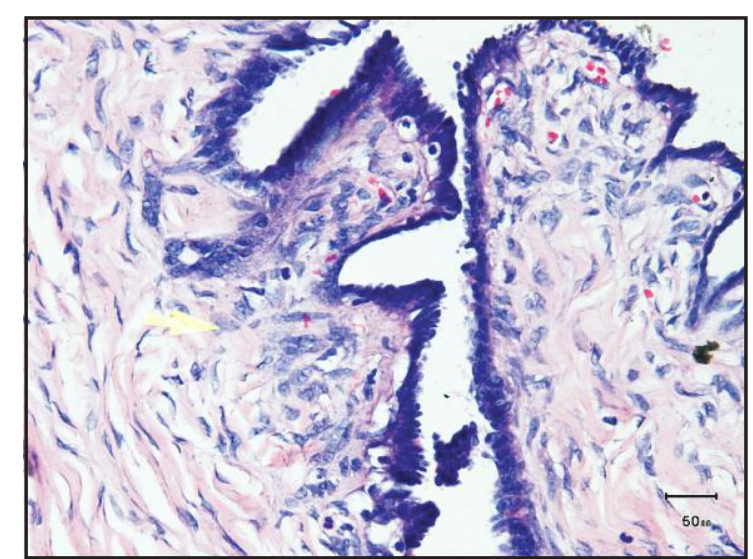

Figure 1 : Serous cyst adenoma 400x (H/P section).

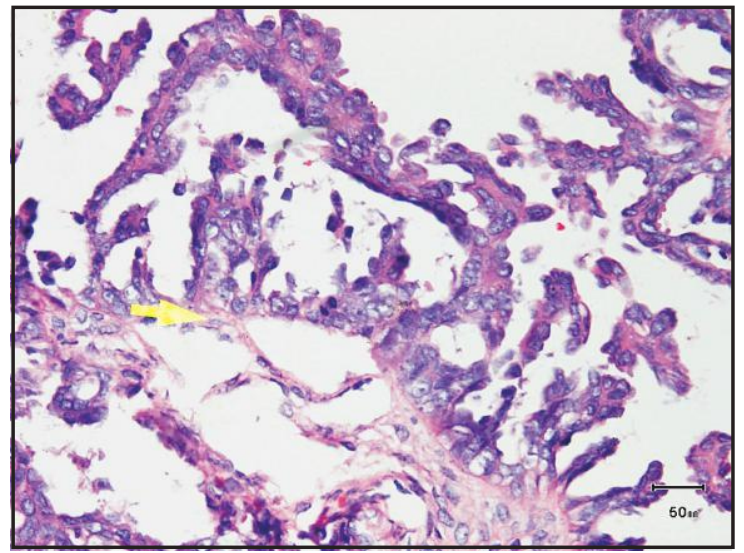

Figure 2 : Serous cyst adenocarcinoma 400x (H/P section).

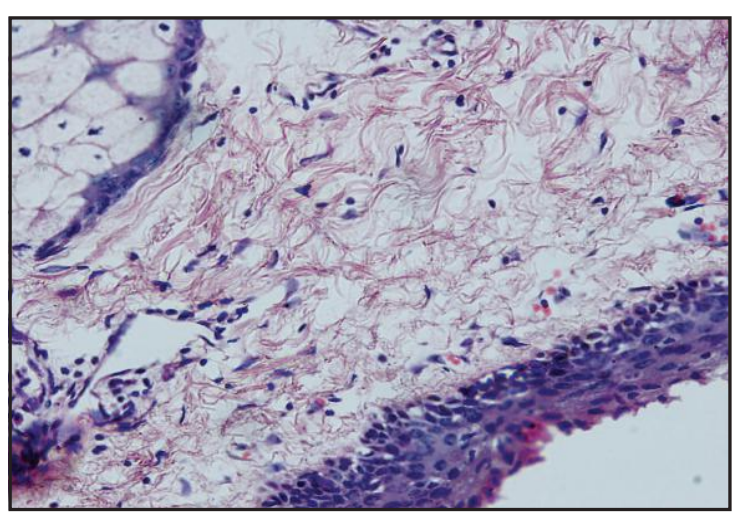

Figure 3 : Mature teratoma 400x (H/P section).

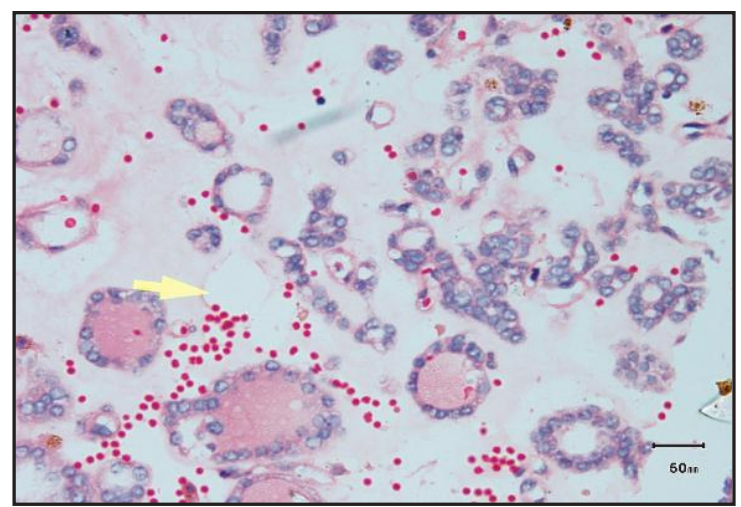

Figure 4 : Struma Ovarii 400x (H/P section). 


\section{DISCUSSION}

Total number of the patients in this study were 69 . The age range was $13-70$ years. The mean age was 36.38 years. Patients were divided into six groups consisting of each decade as a single group and maximum number of patients $20(29.0 \%)$ were in 21-30 years group, followed by $16(23.2 \%)$ were in $31-40$ years age group. Study done by Vaidya et al Showed highest number of patients (58\%) were in 21-40 years age group which is similar to our study ${ }^{6}$. In this study in 21-40 years age group total number of patients were $36(52.2 \%)$. Study done by Bhagyalakshmi et al patients age ranged from 11-70 years, majority of benign cases and malignant cases were between 21 to 40 years and 41 to 60 years respectively ${ }^{7}$. Tushar et al also showed age ranged from 16 to 70 years with most common benign and malignant cases were 21 to 40 years and 41 to 60 years respectively which was consistent with this study ${ }^{8}$.

In the present study, serum CA-125 level was found only in 37 cases. Out of 37 cases, $26(70.3 \%)$ were benign tumours and 11 (29.7\%) were malignant tumours. Among 26 benign tumours 5 (13.5\%) cases had increased level of CA-125 and 1 (2.7\%) malignant case was found within normal level. Miralles et al and Varughese et al suggested that variety of malignancies and benign conditions courses with increased CA-125 level and it is observed that CA-125 is very important as tumour marker for malignancy ${ }^{9,10}$.

In this study $48(69.6 \%)$ patients presented with lower abdominal pain $45(65.2 \%)$ with lower abdominal mass and 11 $(15.9 \%)$ with vaginal bleeding. Study done by Abbas and Matar in their study showed, abdominal pain $(66.66 \%)$ cases, abdominal mass $(57.83 \%)$ cases and menstrual abnormalities $(2.98 \%)$ cases which is nearer to our study ${ }^{11}$.

Incidence of benign tumours were $(78.3 \%)$ and malignant tumours were $(21.7 \%)$ and there was no borderline malignancy histologically in the present study. Study done by Yogambal et al and Mali et al showed benign tumours were $(78.6 \%)$ and (73\%) respectively. Study done by Pilli et al and Suen et al showed malignant tumours were $(21.9 \%)$ and $(21 \%)$ respective$1 y^{12-15}$. Study done by Yasmine et al showed there was no borderline malignancy. Here percentages of benign and malignant tumours were nearer to our study ${ }^{1}$.
In the present study, surface epithelial tumour was $49(70.6 \%)$ germ cell tumour was $6(8.7 \%)$ sex cord stromal tumour was 4 (5.8\%) and non neoplastic lesions was 10 (14.5\%). Among surface epithelial tumour, serous cyst adenoma was found as the most common diagnosis and comprised 23 (33.4\%). Study done by Dasi et al showed surface epithelial tumour was $(64 \%)$ and serous cyst adenoma was (34\%) which is nearer to our study ${ }^{16}$. Among malignant tumour serous cyst adenocarcinoma 5(7.2\%) was the most common followed by mucinous cyst adenocarcinoma $4(5.8 \%)$. Serous tumour were found to be more common than mucinous. Similar result were reported by Yasmine et $\mathrm{al}^{1}$. Among germ cell tumours mature cystic teratoma 4(5.8\%) was the most common diagnosis. Struma ovarii which is relatively uncommon but in our study we found $1(1.4 \%)$ case.

\section{LIMITATIONS}

This study also has some limitations. The sample size was small, the study period was short and this study was done in patients who underwent surgery and samples were collected from Chittagong Medical College and Hospital only. In spite of these reasons the present study showed more or less acceptable findings with consideration of the observations by others.

\section{CONCLUSION}

Benign tumours are more common than malignant ones. The commonest ovarian tumours in our study are the epithelial tumour. Germ cells tumours are next to epithelial tumour which are more common in adult and adolescent age group. Serous cyst adenoma is the most common benign tumour whereas serous cyst adenocarcinoma most common malignancy. Late reporting is common among malignant ovarian tumours and patients usually present in advanced stages of disease.

\section{DISCLOSURE}

All the authors declared no competing interest. 


\section{REFERENCES}

1. Yasmine S, Yasmine A and Asif M. Clinichistological pattern of ovarian tumours in peshwar region J Ayub med coll Abbottabad.2008;20(4):1015.

2. Permuth WJ and Sellers TA. Epidemiology of ovarian cancer.2009; 492: 1-20.

3. Pelusi G, Taroni B and Flamigni C.Benign ovarian tumours, Frontiers in bioscience.1996;1:861-870.

4. Vijayakumar A. The diagnostic utility of intraoperative cytology in the management of ovarian tumour. J Clin Diagn Res.2013;7(6):1047-1050.

5. Chandra shekhar T, Govindraja $\mathrm{E}$ and Chandana N. The diagnostic accuracy of intraoperative imprint cytology in ovarian tumour. Journal of Dental and Medical sciences.2014; 3( 43): 10614 - 10625.

6. Vadiya S, Sharma P, KCS and Vaidya SA. Spectrum of ovarian tumours in a referral hospital in Nepal, Journal of pathology of Nepal. 2014;4:539-543.

7. Bhagyalakshmi A, Sreelekha A, Sridev S, Chandralekha J, Pravathi G and Venkatalakshmi A. Prospective study of histopathological patterns of ovarian tumours in a tertiary care center. Int J Res and Sci. 2014; 2(2): 448-956.

8. Tushar K, Asaranti K and Mohapatra PC.Intraoperative cytology of ovarian tumouns. J obstet gynecol.2004 ; 55(4):345-349.

9. Miralles C, Orea M, Espana, P, Sanchez A, Cantos B and Cubeclo et al. Cancer antigen 125 associated with multiple benign and malignant pathologies. Ann surg oncol.2003;10(2):150-154.

10. Varughese E, Chennakesavan SK and obermair A. The value of serum CA 125 for the development of virtual follow up strategies for patient with epithelial ovarian cancer. Journal of ovarian Research.2012;5(11):1757-2215.

11. Abbas TR and Mater E. The incidence and histopathological pattern of ovarian tumours in Bab Alsaharia university Nat Sci.2015; 13 (4): 37-41.

12. Yogambal M, Arunalatha $\mathrm{P}$, Chandramoulesswari $\mathrm{K}$ and Palaniappan V. ovarian tumours incidence and distribution in a tertiary referral centre in south India, IOSR Journal of Dental and Medical sciences.2014; 13(2):74-80.

13. Mali M, Vyas B, Gupta S and Deasi H. Ahistological study of ovarian tumours in different age group. Int J Med Sci public health. 2012;3(3):338-341.

14. Pilli GS, Sunitha KP, Dhaded AV and Yenni W. Ovarian tumour a study of 282 cases. J indian Med Associ.2002;100(7):420-424.

15. Suen KC, Wood WS, Syed AA, Quenville NF and Clemen PB. Role of imprint cytology in intraoperative diagnosis, value and limitations. Journal of clinical pathology.1978;31:328-337.

16. Dasi C, Muknhopadhyoy M, Saha AK, Senguptai M,and Dhar G. A cytohistological correlation in ovarian tumours. Journal of Dental and Medical sciences.2014; 13:01-05. 